\title{
DEFINITIONS OF LINGUISTIC AND GRAMMATICAL TERMS ${ }^{1}$
}

active voice: $\quad$ sentence in which the subject performs the action expressed by the verb (vs. passive voice)

(Maria $\underline{\underline{\text { abriu }}}$ a janela.)

antecedent: $\quad$ word, phrase, or clause to which another word (usually a pronoun) refers (Temos um amigo que vai para o Brasil.)

aspirated: $\quad$ consonant released with a puff of breath (the $p$ in Eng. party)

clause: $\quad$ group of words that contains a conjugated verb (see "main clause" / "subordinate clause")

cognates: $\quad$ words that are related through derivation from the same ancestral root (Port. / Sp. / Eng. circular $[<$ Latin circularis $]$ )

conditional sentence in which the subordinate adverb clause expresses a condition and is sentence: introduced by se ("if"), and the main clause expresses the consequence ( $\underline{\text { Se quiséssemos, sairíamos.) }}$

conjugation: class of verbs with similar forms;

a conjugation is identified by the final vowel of the infinitive:

$\begin{array}{ll}\text { 1st conjugation } & \text { (falar) } \\ \text { 2nd conjugation } & \text { (comer }) \\ \text { 3rd conjugation } & \text { (partirr) }\end{array}$

dental: $\quad$ sound produced when the tip of the tongue touches the back of the front teeth (the th in Eng. then / thin)

diacritical mark: symbol added to a letter to show pronunciation (= accent mark) (the tilde over the $a$ in $p \underline{\tilde{a}} o$ )

diphthong: sequence of a vowel and a semivowel occurring within the same syllable: in a "falling" diphthong, the semivowel follows the vowel

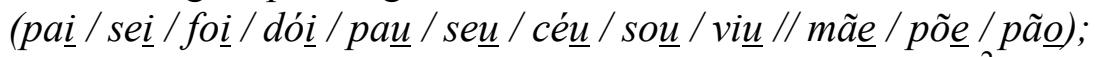
in a "rising" diphthong, the semivowel precedes the vowel ${ }^{2}$ (língua / quarto / qua anto)

${ }^{1}$ Except as indicated, the definitions of the linguistic and grammatical terms used in this book refer specifically to Portuguese, and the examples are in Portuguese. Commonly used terms (e.g., such traditional grammatical categories as "noun" or "verb") are not defined in this list.

2 "Rising" diphthongs (which are frequent in Spanish) are not as frequent in Portuguese as "falling" diphthongs since the sequences of $i / u+$ vowel are often pronounced as vowels in hiatus (see pp. 4: 4, 6: 2 for details). 
direct object: (pro) $\underline{\underline{\text { noun }}}$ that receives the action of a transitive verb ${ }^{1}$

(Ana quer o livro.)

(Ana oq quer.)

gender: classification of (pro)nouns and adjectives to differentiate masculine from feminine:

$-o$ is the most common masculine gender marker (nosso)

$-a$ is the most common feminine gender marker (noss $\underline{a}$ )

hiatus: $\quad$ sequence of vowels occurring in adjacent syllables

(po- $\underline{e}-m a / l \underline{e}-\underline{o}-\underline{a} / R \underline{a}-\underline{u} l / L \underline{u}-\underline{i} s)$

homographs: words identical in spelling but different in meaning

(para o carro [= "for" / "to"] vs. para o carro [= "stops"])

homonyms: $\quad$ words identical in sound but different in meaning

(paço $[=$ "palace"] vs. passo $[=$ "pass" / "step"])

imperative: (see "mood")

indicative: (see "mood")

indirect object: (pro)noun that receives the direct object or is otherwise affected by the verb

(Elas nos deram a revista.)

(Dei o gravador para Ana.)

(A gramática lhe interessa?)

intervocalic: consonant occurring between vowels

(the $r$ in para)

intransitive verb that does not need an object (direct or indirect) to complete its meaning

verb: (vs. transitive verb)

(Nossos primos chegam amanhã.)

main clause: $\quad$ independent clause that does not depend on another clause for its existence (Temos um amigo [que vai para o Brasil.])

marker: indicator of a linguistic category; for example:

$-S \quad$ is the plural marker of (pro)nouns / adjectives (livros / bonitas)

$-r \quad$ is the infinitive marker (falar)

$-n d o$ is the present participle marker (falando)

-mos is the 1st-person plural verb marker (falamos)

${ }^{1}$ An infinitive or a noun clause may also be a direct object:

Ana quer: comprar o livro / que eu compre o livro. 
mood: $\quad$ mode or manner that indicates the speaker's attitude to what (s)he is saying and how an utterance should be perceived;

the verb ending and/or the sentence structure, punctuation, or intonation of the utterance reveal the mood:

indicative: expresses an action or state of being considered

factual, certain, specific, or definite

(Você não canta bem.)

subjunctive: expresses what is felt, or what is uncertain, doubtful, unspecific, indefinite, or negated;

also expresses the condition of a conditional sentence

[future / past subjunctive only]

(Duvidamos que você cante bem.)

(Se você quisesse, cantaria bem.)

imperative: expresses a command, request, instruction, or warning (Cante bem!)

nasal: $\quad$ sound produced when air is released through the nose as well as the mouth (vs. oral)

(the $\tilde{a} o$ in $p \underline{\tilde{a} o}$ )

nominalization: replacement of a noun by an article (+ adjective)

(umas [casas] novas / as nossas [casas])

(= Eng. "[the] one[s]" / "some")

nonrestrictive subordinate clause that does not give essential information about the antecedent;

clause: $\quad$ a nonrestrictive clause is usually contained within commas

(vs. restrictive clause)

(Nosso amigo, que é brasileiro, chega amanhã.)

number: $\quad$ classification of (pro)nouns, adjectives, and verb forms to differentiate singular from plural:

$-s$ is the plural marker of (pro)nouns / adjectives (livros / bonitas)

object: $\quad$ (pro)noun that is acted upon or governed by a verb or a preposition; an object completes the meaning of the verb or the preposition (see "direct object" / "indirect object" / "prepositional object" / "reflexive object")

oral: $\quad$ sound produced when air is released through the mouth

(vs. nasal)

(the $a u$ in $p \underline{a u}$ )

orthographic: relating to orthography (= rules of spelling);

before a letter, it also means "written but not necessarily pronounced"

(the $n$ in penso) 
orthography- verb in which an orthographic change must be made in certain forms

changing verb: in order to transcribe correctly a sound in the radical of the infinitive

$$
\text { (proteger }>\text { protejo) }
$$

oxytone: $\quad$ word stressed on the last syllable

$$
\text { (animal) }
$$

paroxytone: word stressed on the next-to-last syllable

$$
\text { (classe) }
$$

passive voice: sentence in which the subject receives the action expressed by the verb and is acted upon by an "agent" (which may or not be expressed)

(vs. active voice)

$$
\text { (A janela foi aberta [por Maria].) }
$$

person: classification of pronouns and corresponding verb forms to indicate the relationship between the speaker and the listener(s) of an utterance, and their relationship to another grammatical subject;

the verb ending and/or the subject reveal the person:

1st person: used when the subject is the speaker (+ another person[s])

$$
\text { (eu canto // nós cantamos) }
$$

2nd person: used when the subject is the listener(s)

$$
\text { (tu cantas // vós cantais) }
$$

3rd person: used when the subject is not the speaker or the listener

$$
\text { (ele / ela canta // eles / elas cantam) }
$$

phonetic: $\quad$ relating to speech sounds

phrase: $\quad$ group of words that is not a complete sentence because it does not contain a conjugated verb

(Estando João na cozinha, Maria abriu a janela.)

poststressed: $\quad$ sound, letter, or syllable occurring after a stressed syllable (the $a$ in $u s \underline{a}$ )

predicate noun: noun that describes or identifies the subject;

a predicate noun normally follows the main verb

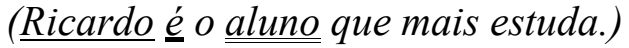

prepositional (pro)noun that follows a preposition and completes its meaning ${ }^{1}$

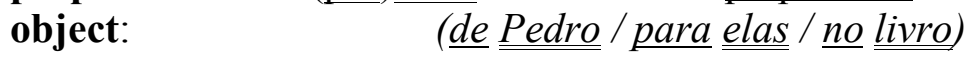

${ }^{1}$ An infinitive or a noun clause may also be a prepositional object:

Ana insiste em: comprar o livro / que eu compre o livro. 
prepositional phrase consisting of a preposition and its (pro)noun object;

phrase:

prepositional phrases function as adjectives or adverbs

$$
\begin{aligned}
& \text { (O piano é de madeira.) (= adjective [prepositional] phrase) } \\
& \text { (A festa é no clube.) (= adverb [prepositional] phrase) }
\end{aligned}
$$

prestressed: $\quad$ sound, letter, or syllable occurring before a stressed syllable (the $u$ in $\underline{u} s a r$ )

"progressive": verb tenses and forms consisting of estar ("to be") + present participle e $^{1,2}$

(Vocês estavam comendo?)

proparoxytone: word stressed on the second-to-last syllable

(gramática)

radical: $\quad$ stem $(=$ root $)$ of a verb

(vs. ending)

(falar / comeu / partia)

radical- $\quad$ verb in which a sound in the radical changes in certain forms

changing verb: (= stem-changing verb)

$$
\text { (dormir }>\text { durmo) }
$$

reflexive object: direct or indirect object that reflects or refers back to the subject

$$
\begin{array}{lll}
\text { (Ela se levantou. }) & \text { ("herself") } & \text { (= direct object) } \\
\text { (Eles } \underline{\underline{\text { se }} \text { compraram uma moto.) }} & \text { ("themselves") } & \text { (= indirect object) }
\end{array}
$$

reflexive verb: $\underline{\underline{\text { verb }}}$ that needs a reflexive object to complete its meaning (Quem se suicidou?)

restrictive

clause: subordinate clause that gives essential information about the antecedent; a restrictive clause is not usually contained within commas (vs. nonrestrictive clause)

(O único amigo nosso que é brasileiro chega amanhã.)

semantic: $\quad$ relating to meaning

1 andar / ficar / ir / vir occasionally replace estar in the "progressive."

2 EP: The "progressive" consists of estar $a+$ impersonal infinitive (Vocês estavam a comer?). 
semivowel: $\quad$ vowel-like unstressed sound that functions as a consonant by forming a diphthong with a contiguous vowel articulated within the same syllable (= "glide"); ${ }^{1}$

the two Portuguese semivowels are transcribed $\boldsymbol{i}\left[{ }^{\mathrm{i}}\right]$ and $\boldsymbol{u}\left[{ }^{\mathbf{u}}\right]$

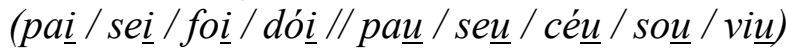

stress(ed): $\quad$ relative force with which a sound or a syllable is uttered

(the $a$ in ano / sofá / caso / Mário)

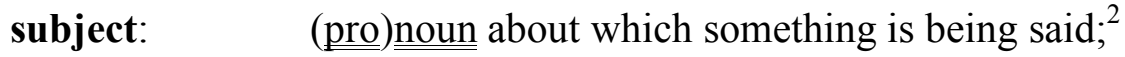

the subject often performs the action of the verb

(Quem comprou o livro? Ana o comprou.)

subjunctive: (see "mood")

subordinate dependent clause that depends on the main clause for its existence;

clause: $\quad$ subordinate clauses function as nouns, adjectives, or adverbs

\begin{tabular}{|c|c|}
\hline que você vá & oun clause) \\
\hline vai para o Brasil.) & ause) \\
\hline
\end{tabular}

syllable-final: sound or letter occurring at the end of a syllable

(the $r$ in carne)

syllable-initial: sound or letter occurring at the beginning of a syllable

(the $n$ in carne)

tense: classification of verb forms to indicate the time of the action or state of being in relation to the time of the utterance; for example, in the utterance

"João diz que irá, " the action of the future-tense verb (irá) will occur in the future with respect to the present time of the utterance (diz); in the utterance "João disse que iria, , the action of the conditional-tense verb (iria) would occur in the future with respect to the past time of the utterance (disse).

transitive verb: $\underline{\underline{\text { verb }}}$ that needs a direct object to complete its meaning ${ }^{3}$

(vs. intransitive verb) (Adoro o seu cachorro!)

${ }^{1}$ Some linguists distinguish between a "semivowel," which ends a "falling" diphthong (causa), and a "semiconsonant," which begins a "rising" diphthong (quarto).

${ }^{2}$ An infinitive or a noun clause may also be a subject:

É preciso: comprar o livro / que eu compre o livro.

${ }^{3}$ A ditransitive verb needs both a direct object and an indirect object to complete its meaning:

Os meus pais nos compraram uma casa. 
verb group: conjugated verb $+\underline{\underline{v e r b a l}}$

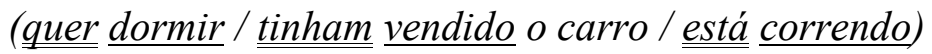

verbals: $\quad$ infinitives / past participles / present participles; ${ }^{1}$ these forms derive from verbs but may also function as nouns, adjectives, or adverbs, respectively

(é preciso dormir / o carro foi vendido / chegou correndo)

voiced: $\quad$ consonant sounds $[\mathbf{b}] /[\mathbf{d}] /[\mathbf{g}] /[\mathbf{v}] /[\mathbf{z}] /[\check{\mathbf{z}}] /[\mathbf{l}] /[\boldsymbol{\lambda}] /[\mathbf{r}] /[\mathbf{m}] /[\mathbf{n}] /[\mathbf{n}]$, the voiced variants of $/ \mathbf{R} /(=[\mathrm{R}] /[\mathrm{r}])$, and all vowels, produced when the vocal cords vibrate

voiceless: $\quad$ consonant sounds $[\mathbf{p}] /[\mathbf{t}] /[\mathbf{k}] /[\mathbf{f}] /[\mathbf{s}] /[\check{\mathbf{s}}]$ and the voiceless variants of $/ \mathbf{R} /(=[\mathrm{h}] /[\mathrm{x}])$, produced when the vocal cords do not vibrate

word-final: sound or letter occurring at the end of a word (the $\tilde{a}$ in irm $\tilde{a}$ )

word-initial: sound or letter occurring at the beginning of a word (the $i$ in $\underline{i} r m \tilde{a}$ )

${ }^{1}$ See p. $211 \mathrm{nn} 1-2$ concerning the terms present participle and gerund. 